demonstrates the various methods, both old and new, which are used to correlate geological formations from well to well, thus enabling the underground geological structure to be determined. A panel which discusses oil reservoir problems directs attention to one of the most important problems of the industry at the present time, that of producing all the oil contained within the reservoir rock; at the best, current production practice may recover only about 75 per cent of the oil originally stored within the reservoir.

The final sections on transport and refining, and distribution and products, also contains maps by Bip Pares, one of which, namely, that illustrating the world movement of oil in relation to tanker movements, is on an original projection. Of special interest is a series of photographs illustrating the construction of a pipe-line, and the cathodic protection methods employed to combat corrosion. A novel exhibit in the section on refining methods is a large coloured flow-chart which outlines the main refining processes, and of more specialized interest there is a number of smaller panels each illustrating in detail the stages of one refining process and including within the panels samples of the refined products. Another map shows the position of refineries in Great Britain and directs attention to the great development in refining that has taken place in the past five years. Chemical research in the industry is outlined on a panel which illustrates research in the laboratory and the use of petroleum derivatives for agricultural purposes.

As a final section of the exhibition, there are examples of the work of British manufacturers of oilfield equipment and a demonstration of the work of the Petroleum Information Bureau in the form of a display of leaflets and posters which discuss the various aspects of the industry.

Accompanying the exhibition three programmes of films are being shown daily under the auspices of the Petroleum Films Bureau, and in addition there is a special arrangement by which any film listed by the Bureau will be shown on request.

The oil companies are to be congratulated on a most interesting and informative exhibition, which not only well demonstrates the wide scope of the industry and the problems it is facing, but also serves to publicize the enterprise and achievements of British companies in the petroleum world.

C. A. Fothergili

\section{PROBLEMS OF THE NATIONALIZED INDUSTRIES OF GREAT BRITAIN}

$\mathrm{T}$

HE Acton Society Trust is issuing a series of papers in which an objective analysis of some of the problems of nationalized industry is attempted. The series* is edited by G. R. Taylor, and the first two pamphlets issued deal with "Accountability to Parliament" and with the "Powers of the Minister".

The first of these examines the reasons why Parliamentary control of the nationalized industries has not proved wholly satisfactory, and gives alternative or additional methods of supervision which might be employed. There is also appended an analysis of questions put in the House of Commons relating to

* Nationalized Industry Series : No. 1, Accountability to Parliament (pp. 33, 1950); No. 2, Powers of the Minister (pp. 20, 1951); No. 3, Problems of Promotion Policy (pp. 20, 1951). (Acton Suciety Trust, Acton House, Church Road, Claygate, Esher,
Surrey.) 2s. each. the nationalized industries. Briefly, Parliamentary control has been unsatisfactory because the flow of information to Parliament is inadequate and behindhand, and because members, in general, have not proved capable of assessing the highly technical problems involved and of pointing out with unanimous voice what is wrong. For Parliament to function more effectively, more frequent debates would be necessary and also attainment of a higher level in the debates, while Parliament would require more detailed information on which to base its judgment. A second alternative would be to transfer some part of the burden to a body other than Parliament. The pamphlet points out, however, that the question whether the public corporation is the most satisfactory means of operating nationalized industry should not be prejudged: the form of industrial ownership most consistent with social justice and public accountability may be of a different character altogether. More radical thinking is required, and a satisfactory solution is likely to be difficult while the principal political parties are sharply divided on the issue of nationalization itself.

The second pamphlet, after summarizing the statutory powers which have been given to the Ministers responsible for the newly nationalized industries and examining the use which has been made of those powers, discusses the proper role of the Minister with the view of determining what those powers should be. The conclusion is reached that the very extensive, not to say absolute, powers which the Ministers possess have been used with extreme caution, but that the situation is unsatisfactory because Parliament has developed no clear idea of the Minister's functions or of how close its supervision of the nationalized industries should be. That must be the first step towards a definite solution; but the present powers of Ministers appear to be somewhat excessive, and urgent consideration of the dispersal of some part of the Minister's powers among other bodies or persons and, where this is impossible, of the establishment of checks or balances, is recommended.

Whatever powers are left to the Minister, adequate safeguards have still to be created against a possible abuse of power. Some alarm is expressed, in par.ticular, at the Minister's power to prevent the disclosure of his own actions when, in his own opinion, it is not in the interests of security to do so, and surprise is expressed that any Parliament should have been prepared to assent to such a condition. The present situation, it is urged in this pamphlet, cannot be regarded with equanimity by those who are concerned with political freedom, even if the assumptions are made (none of which are above question) that industry must necessarily be operated on the national scale, that control must be largely centralized, that government itself must be highly centralized, and that commercial undertakings can best be supervised by a political body divided on party lines.

A third pamphlet in the same series, "Problems of Promotion Policy", brings out two grave dangers that procedures and policies in the nationalized industries present: first, the conflict between the desire for promotion by seniority and the need for a satisfactory standard of efficiency and service has not been faced; and secondly, there is a tendency to build up a rigid and elaborate system of regulations which both fails to secure justice and at the same time reduces efficiency and flexibility. 